\title{
"It Just Works Better": Introducing the 2:1 Model of Co-Teaching in Teacher Preparation
}

\author{
Christina M. Tschida
}

Judith J. Smith

Elizabeth A. Fogarty

East Carolina University

\begin{abstract}
Many issues influence reform in teacher preparation including national accountability efforts, professional teaching standards, and local or regional factors. This study examines a rurally-located teacher education program's efforts to reform clinical preparation through co-teaching. Researchers argue that their adaption of the typical one-to-one (1:1) model of co-teaching to a two-to-one (2:1) model, where two teacher candidates work collaboratively with one cooperating teacher, greatly enhances the student teaching experience. This phenomenological research describes the first year of implementation. Despite cooperating teacher concerns about teacher candidates being prepared for their own classrooms, student teachers learned valuable lessons in collaboration and co-planning, built strong relationships with peers and cooperating teachers, and greatly impacted $\mathrm{K}-6$ student learning. Implications suggest a 2:1 co-teaching model of student teaching allows for fewer placements, which ultimately allows selection of quality cooperating teachers who mentor teacher candidates in powerful ways.
\end{abstract}

\section{Keywords: co-teaching, student teaching, teacher preparation, rural education, clinical field experience}

Since the 1920 s to the early 2000 s, the student teaching experience remained significantly unchanged (Guyton \& McIntyre, 1990), but in the past decade, reforms to teacher education have gained both momentum and attention in educational research. Reports of teacher education reform efforts have recognized the need to more closely examine the role of this vital experience in preparing effective teachers (Cochran-Smith \& Fries, 2001; Delandshere \& Petrosky, 2004; Wang, Odell, Klecka, Spalding, \& Lin, 2010). According to the Council of Chief State School Officers (2012), clinically-based preparation programs must provide relevant, well-planned experiences to prepare teacher candidates. However, large teacher education programs and those located in rural areas face significant challenges in placing student teachers in quality field experiences. This is due to inadequate numbers of cooperating teachers or schools that are willing to host interns (Goodlad, 1994; Ladson-Billings, 2001; Sinclair, Dawson, \& Thistleton-Marting, 2006; Zeichner, 2002).

Cooperating teachers who agree to host a teacher candidate are often unqualified to model best practices for the novice intern or may not have the necessary mentoring skills. This is particularly concerning because the cooperating teacher has been found to have the most significant impact on teacher candidates (Anderson, 2009; Killian \& Wilkins, 2009; Whitney, Golez, Nagel, \& Nieto, 2002). In its 2012 report for transforming educator preparation and entry into the profession, The Council of Chief State School Officers advocated for a screening process for identifying cooperating teachers, as well as providing training to demonstrate effective instructional practices and to positively impact student achievement. Such a process can further 
contribute to the difficulties experienced by large rural teacher education programs in finding quality placements for their teacher candidates.

To overcome the challenges of placing large numbers of teacher candidates in rural public schools and to strengthen the teacher education program, the College of Education at a large southeastern regional university is engaged in teacher preparation reform, utilizing the co-teaching model of student teaching. This model offers training to cooperating teachers and teacher candidates on co-teaching strategies for instruction and collaborative planning. The College of Education is experimenting with different coteaching models including the more commonly known 1:1 model, which involves one cooperating teacher and one teacher candidate. It is also experimenting with a 2:1 model (i.e., two teacher candidates and one cooperating teacher) and a 2:2 model (i.e., two teacher candidates and two cooperating teachers work together). Co-teaching should significantly reduce the number of internship placements needed, thereby enabling the Office of Teacher Education to be more selective in choosing cooperating teachers. This article reports on the initial year of implementation of this new co-teaching model, with specific attention to the 2:1 model, which may offer the best opportunities for meeting the challenges faced by large rural teacher education programs.

\section{Situating Co-Teaching Within Teacher Preparation Reform}

The term co-teaching is typically associated with special education or inclusion classrooms. More recently it is being used in regular classrooms at the BK-12 level as well as in teacher preparation. We will introduce co-teaching and build a rationale for using co-teaching in teacher preparation that is rooted in both the literature and current educational reforms.

\section{What is Co-Teaching?}

Co-teaching initially began as a collaborative between general education and special education in response to Public Law 94-142 Individuals with Disabilities Education Act (IDEA) legislation to support students with disabilities in general education classrooms (Austin, 2001; Boucka, 2007; Cook \& Friend, 1995; Hang \& Rabren, 2009; Vaughn, Schumm, \& Arguelle, 1997). Though definitions of co-teaching vary, most educators agree that coteaching involves two or more adults collaborating to instruct groups of students (Adams, Cessna, \& Friend, 1993; Beninghof, 2011). Early on, coteaching involved both classroom and special education teachers, with general educators having content knowledge and special educators having expertise in instructional processes to teach individual students who may learn in atypical ways (Adams \& Cessna, 1991; Reeve \& Hallahan, 1994). One of the most beneficial aspects of co-teaching is that both teachers plan and deliver lessons together based on student needs (Sileo, 2005).

During the early 1990s, Marilyn Friend did much of the early work on redesigning special education to improve outcomes for students through inclusion and co-teaching (Friend, 1995). Her work paved the way for various implementations of co-teaching models in schools and much research on their effects (Bauwens \& Hourcade, 1991, 1997; Cook \& Friend, 1995; Friend, 2001; Reeve \& Hallahan, 1994; Sileo, 2005). Friend (1995) identified seven instructional strategies that are used by two or more classroom and special education teachers to ensure and improve student learning. All strategies involve both (or all) teachers in the instruction, decrease student-to-teacher ratio, and provide differentiated ways for students to learn content or skills.

\section{A Rationale for Adopting the Co-Teaching Model in Teacher Preparation}

Building on this promising model of teaching in special education, the Academy for Co-Teaching and Collaboration at St. Cloud State University (2012)

applied co-teaching to the student teaching experience, thus enabling two professionally prepared adults to collaborate in the classroom. This new model of student teaching allows cooperating teachers to collaborate with teacher candidates in new ways on planning, organization of physical space and materials, and delivery and assessment of instruction. 
Both cooperating teacher and teacher candidate(s) are actively involved and engaged in all aspects of instruction. At St. Cloud State University, coteaching strategies have been applied successfully to student teaching at all grade levels and in every content area from preschool to senior high. Analyzing the cumulative student achievement data gathered between 2003 and 2007, St. Cloud State University found statistically significant gains in reading and math proficiency when comparing 35,000 P-12 students in co-taught versus non cotaught student teaching settings.

Following St. Cloud State University's success, other teacher preparation institutions have begun exploring the co-teaching model of student teaching. This new co-teaching model offers different opportunities for collaboration compared to traditional models of teacher preparation. Teacher candidates become an integral part of preparation for and delivery of instruction, as well as partners in assessment and data-driven planning. Both teacher educators and teacher candidates see such collaborative learning as yielding positive results in teacher preparation (Ruys, Van Keer, \& Aelterman, 2010). Carambo and Stickney (2009) suggest that coteaching is better than the traditional model for student teaching because it takes away the sharp distinction between the beginning teacher candidate and the experienced classroom teacher.

Another consideration for co-teaching in teacher preparation may help address the growing concern of cooperating teachers and school districts over new teacher evaluation standards linked directly to student achievement. According to a 2011 report by the National Council on Teacher Quality, 23 states include student growth or value-added data in teacher evaluations, with 17 of them using student achievement as a "significant" criterion in evaluation of teachers. The pressures associated with this new evaluation standard, tied directly to student achievement, create an environment where teachers feel uncertain about turning over their classrooms to a novice student teacher (Sinclair et al., 2006; Zeichner, 2002). Finding qualified cooperating teachers who can model best practices and theory taught in teacher education courses, in addition to mentoring a novice teacher effectively, becomes increasingly difficult.

\section{The Significance of Quality Clinical Experiences in Rural Areas}

For large teacher preparation programs and particularly those situated in rural areas, the clinical placement problem becomes even more challenging. Researchers in Canada and Australia have been investigating issues of preparing teachers for work in remote places and teacher education clinical placements in rural areas for several decades (see for example, Hudson \& Hudson, 2008; Lock, Reid, Green, Hastings, Cooper, \& White, 2009; Murphy \& Cross, 1990; Ralph, 2002; Sharplin, 2002; Yarrow, Ballantyne, Hansford, Herschell, \& Millwater, 1999). Research in rural teacher preparation in the United States tends to focus on specific programs with rural practicum experiences in sites often located a great distance from the university. Alternatively, it analyzes the importance and challenges of preparing teaching candidates to teach in rural settings through curricular or program efforts (see for example, Barley, 2009; Jones, 2011; Nganga \& Laughlin, 2011; White \& Kline, 2012). Considerable work in curricular or program changes and educational research has focused on preparing teachers for diversity within the classroom and cultural issues in urban education (Gay, 2000; Gollnick \& Chinn, 2009; Irvine, 2003; Ladson-Billings, 2004). While this research is important, it is equally significant to examine teacher education programs located within rural regions and the experiences of the student teachers, cooperating teachers, and university supervisors involved in teacher preparation.

In 2006, the National Center for Education Statistics created a new classification system with four locale categories (i.e., city, suburban, town, and rural) and three subcategories for each. Under this system, $63 \%$ of the nation's students are enrolled in public schools classified as either city or suburban, while $37 \%$ attend either rural or town classified schools. The report also states that a majority of rural teachers (64\%) view implementation of the Common Core as challenging or very challenging. Nearly $8,000(56 \%)$ of the public school districts in the United States are located in rural areas and contain 
about one-third (31\%) of the nation's public schools (Harmon \& Smith, 2012). Given these statistics, preparing teacher candidates for both rural and urban settings is important and providing quality clinical experiences for teacher candidates in rural areas can be challenging.

\section{Method}

As a large university situated in a rural region of southeastern United States, the College of Education featured in this study has a long tradition of producing large numbers of teachers for the regional school districts. In this state, more students are enrolled in rural or small town public schools (61\%) than are enrolled in suburban or urban areas (39\%). This is nearly the reverse of statistics for the overall United States, where $63.3 \%$ of students live in urban or suburban areas and $36.7 \%$ live in small towns or rural areas (National Center for Education Statistics, 2012). Within this context, the College of Education places hundreds of teacher candidates in predominantly rural public schools each year. This is not an easy task considering the number of interns and limited opportunities for placements due to the remote nature of regional districts. The pressures of student and teacher accountability, as discussed above, further limit quality clinical placements.

These challenges led to an exploration for clinical preparation reform in the College of Education. Research on the St. Cloud State University co-teaching model for student teaching motivated an initial pilot study within the elementary education program. Finding success with the $2: 1$ model of co-teaching in one classroom brought forth a mixed-methods study designed to look at participants' perceptions, efficacy, and growth in collaboration and teaching. It was also created to study the experience of K-12 students in co-teaching versus non co-teaching classrooms using a small group of teacher candidates in both the elementary program and special education program (where coteaching was a natural fit). This article reports on the qualitative data from focus groups, interviews, and survey data collected in the first year of implementation of the new co-teaching model (20122013).

\section{Research Design}

To explore the experience of teacher candidates and cooperating teachers, researchers focused on the qualitative data collected in the larger mixed methods study. Qualitative research allows one to "investigate a phenomenon, population, or general condition" . (Stake, 2000, p. 445) and to provide better insight into the process or issue being studied (Creswell, 2005). In this case, the phenomenon under investigation was the use of the $2: 1$ co-teaching model in which two candidates are placed with one cooperating teacher. The research questions that guided this study were:

1. What does a 2:1 co-teaching model of student teaching look like?

2. What are the benefits and drawbacks of a $2: 1$ co-teaching model for student teaching in rural settings?

A qualitative approach was used to find descriptions for the 2:1 co-teaching model and better understand how it impacted the teacher candidates.

\section{The Participants and Context}

Study participation was comprised of three main groups including teacher candidates, cooperating teachers and university supervisors. Twenty-five teacher candidates were randomly selected for the coteaching placements from a total pool of 210 candidates in elementary education and special education. There were 14 cooperating teachers from two local school districts identified by principals or themselves as willing to participate in co-teaching. In addition, the six university supervisors assigned to the teacher candidates selected to be in co-teaching were also asked to participate. Table 1 shows the breakdown for teacher candidates in both co-teaching and non co-teaching placements. 
Table 1

Type of Placement by Program

\begin{tabular}{lccc}
\hline \multicolumn{1}{c}{ Program } & $1: 1$ Co-Teaching & $2: 1$ Co-Teaching & $\begin{array}{c}\text { Non Co-Teaching (Traditional } \\
\text { Student Teaching) }\end{array}$ \\
\hline Elementary & 3 classrooms & & 152 classrooms \\
Special Education & NA $=3$ students $)$ & $(\mathrm{n}=18$ students $)$ & $(\mathrm{n}=143$ students $)$ \\
Total Number of & 3 classrooms & 2 classrooms & 44 classrooms \\
Placements & $(\mathrm{n}=3$ students $)$ & 11 classrooms & $(\mathrm{n}=42$ students $)$ \\
& $(\mathrm{n}=22$ students $)$ & 196 classrooms \\
\end{tabular}

The university is located within District A. District B is a neighboring district with schools located within 45 minutes of the university. Both are classified as rural districts, with 37 schools comprising District A, and only six schools comprising District B (National Center for Education Statistics, 2012). All participants were provided approximately five hours of training on strategies for co-teaching and collaboration during the fall of 2012. In the spring semester, teacher candidates completed their student teaching and were asked to implement the coteaching strategies with their cooperating teachers.

\section{Data Collection}

While multiple sources of data were collected for a larger study, this article focuses only on the qualitative data including focus groups or interviews with cooperating teachers, teacher candidates, and university supervisors from the spring of 2013, plus a co-teaching survey completed by teacher candidates at the end of their student teaching experience.

Separate focus groups were scheduled for teacher candidates and cooperating teachers. Five focus groups were held for teacher candidates with approximately 4-5 candidates in each group. These focus groups lasted approximately an hour. Two focus groups were attended by six of the cooperating teachers. Additionally, interviews were held with the remaining 14 university supervisors and cooperating teachers.

\section{Instruments}

Two instruments were used: first a semi-structured interview protocol, and second, the co-teaching survey.

The same semi-structured interview protocol was administered to all participants in the study including teacher candidates, cooperating teachers, and university supervisors. The protocol included five open-ended questions, which were read to the participants and all responses were audio recorded for later transcription. The five questions were as follows:

1. Briefly describe your experience with coteaching this semester and how it has differed from your past involvement with the internship experience.

2. What were the positive aspects of your experience with co-teaching? Give any specific examples you may have. 
3. What negative aspects did you experience with co-teaching? Give any specific examples you may have.

4. Do you think that co-teaching would have a positive effect if it were to become a regular part of the internship teaching experience at the university? Why or why not?

5. Are there any other comments that you have about your experience with co-teaching this semester?

The Co-Teaching Survey is a survey instrument designed by the researchers for use in this study to determine teacher candidates' perceptions of their student teaching experience. All teacher candidates were asked to respond to the following open-ended questions: "Do you feel the internship path (coteaching or not) you traveled was best for you? Why or why not?" It is noted that at the university in the study, the student teaching experience is termed as the "internship" and is referred to as such in the survey. Those candidates who participated in the 2:1 co-teaching placements were also asked to respond to two additional questions. The survey stated: "For those working with another student intern, please describe your experience working with another student during your internship experience. What were the benefits? What were the drawbacks?" The openended responses were analyzed for this article.

\section{Data Analysis}

Focus groups and interviews were audio recorded and then transcribed. Transcriptions of all focus groups and interviews were stored electronically and organized using NVivo software. Initial coding of the focus group and interview data was conducted using two a priori categories: the benefits and the drawbacks of the co-teaching model. Additional categories emerged as researchers ran word frequencies and phrase analysis. The data from these categories were printed and then reanalyzed and sorted by researchers both individually and then together to improve reliability. This process allowed researchers to collapse the eight categories into four: relationships, impact on students, preparation for teaching, and collaboration. Follow up conversations occurred with participants and were used to check the accuracy of the themes. Each category is discussed in the next section. These findings were further triangulated using the co-teaching survey data.

\section{Findings}

Teacher candidates and cooperating teachers who participated in the 2:1 co-teaching model reported stronger relationships with their co-teachers, greater impact on students, efficacy in their readiness to teach, and gains in collaborative skills.

\section{"Breathing Each Other's Air": Relationship Building in Co-Teaching}

Teacher candidates were randomly assigned to co-teaching partnerships, which meant that most did not know each another when they started their internship. The majority of 2:1 co-teaching interns quickly bonded, realizing they were not alone during this challenging time of their teacher preparation. One teacher candidate explained, "It was hard for us but . . . it really did help my stress level because I didn't feel so alone doing [student teaching] . . . I'm glad I got to do it [co-teaching]." An intern comment on the co-teaching survey conveyed similar feelings: "I had someone other than my experienced CT [cooperating teacher] to give extra support and guidance. It was a lot less stressful than I thought it would be." For one set of co-interns the relationship was immediate, "It honestly fell right in place. The kids think we're sisters."

Teacher candidates also reported positive relationships with their cooperating teachers. "My clinical teacher is always there either by text, phone, or email...we are always together, we work together all the time, we see each other outside of school," explained one teacher candidate. Her experience was different than her peers in non co-teaching placements who told her they only saw their cooperating teacher during the school day. She explained further:

I don't know if that was what [co-teaching] was supposed to do, but for us, it works. I feel that we have that working relationship where we can always bounce ideas off of each other. Whereas, my peers on the other hand, they have a standoffish approach with their clinical teacher.

A second teacher candidate had a similar experience with her cooperating teacher and commented on the impact of having a good relationship. She commented, "If you didn't have a 
good relationship with your clinical teacher, it would have been really miserable, but we got along, [coteaching] really forces you to be closer with your clinical teacher."

As the co-teaching teams built strong relationships, a level of trust grew that allowed cooperating teachers to jump in and correct any misinformation or incorrect content during an intern's lesson. This is unlike the traditional model where teachers wait to offer feedback until the debriefing following the lesson-meaning they would also have to go back and correct misinformation to the students at a later point. Because cooperating teachers could interject information or clarifications during the lessons, interns felt less pressure to be absolutely correct in content and teaching all of the time and trusted their cooperating teacher would help guide them during lessons if needed. One of the cooperating teachers explained these opportunities where she interjected information or clarification into a lesson by saying, "It's never done condescendingly, it's just very natural ... it's okay for us to come in [and help] and it takes the monkey off their backs a little." Such coteaching allowed interns opportunities for growth rather than moments of "failure". As time went on, interns also found themselves able to assist the lead teacher (whether it was a co-intern or the cooperating teacher) without feeling like they were interrupting, but rather were focused on student learning.

A university supervisor explained an advantage of the 2:1 model saying; "It was so much better in the classroom because [they] looked out for each other's back." Another university supervisor observed,

I like how when one of them is teaching the other one just gets up and sees what needs to be done and just does it. It becomes so natural the way they flow in and out of each other's lessons. It's really been something to watch.

While the majority of teacher candidates found it fairly easy to connect with their co-intern and cooperating teacher, a few groups struggled initially to make the connections needed for a successful coteaching pairing and collaborative planning. As one cooperating teacher recalled initially, "It was just a total mismatch between the three [of them]."
In a couple instances, the university supervisor stepped in and worked closely with the cooperating teacher and co-interns to build a positive working relationship and develop collaborative skills needed for co-planning and co-teaching.

For successful collaborative work in the 2:1 coteaching model, all participants named relationships as a key element. Several even suggested the use of some kind of inventory or interview process to select teacher candidates to participate in co-teaching. Many cooperating teachers said they would do coteaching again, but only if they were assigned interns matched as well as those they had that year. The reality was all teacher candidates were assigned randomly and no measures were taken to ensure compatibility. The strong working relationships that formed between the co-teachers came from the need to collaborate often and be actively involved in the planning, instruction, assessment, and management of the classroom. These positive relationships allowed not only growth in interns' teaching readiness, but ultimately improved student learning and success in the classroom.

\section{"It Impacted My Students Immensely": The Effect of Co-Teaching on Students}

According to one cooperating teacher, coteaching is "not just someone sitting in the room watching and then getting up to teach a lesson once in a while. [The students] just feel like we're all their teacher." From day one, teacher candidates were actively involved in the co-teaching classroom. They assisted struggling students, pulled small groups, corrected misbehavior, and redirected off-task students. They worked with the cooperating teacher closely to monitor student learning and modify lessons to meet student needs. In other words, the teacher candidates in the co-teaching classrooms hit the ground running on their first day of internship and worked collaboratively through to their last day, essentially tripling the number of trained teachers in the classroom.

Cooperating teachers noted that having extra teachers in the classroom minimized behavioral issues by keeping students on task, lowered the student-teacher ratio, and cut out wait time. They made comments such as: 
We don't have the behavior issues ... [it helps] the children who are frustrated or who might not get what I'm teaching . . . they don't have to wait.

You definitely get more one-on-one attention with children. You can break children up into smaller groups, which is much better. We saw better results.

I was able to take [the student] aside, get manipulatives, and work with him on his level ... like tracing numbers and letters ... and if I wasn't there he would just be up out of his seat and disturbing the other students from learning. That was really positive for us.

In addition, the 2:1 co-teaching model provided the opportunity for differentiation, which made a huge impact on student achievement. One cooperating teacher commented, "It's really nice to have somebody [assisting] when you do reading groups at this age level. That's kind of a utopian! We've done it [divided into groups] in math, science, writing, everywhere and it's been great."

Understanding the value of differentiating instruction, cooperating teachers expressed gratitude for the way the co-teaching model provided more opportunities for them to differentiate for their students than traditional student teaching. The following comments exemplify the overall feelings from cooperating teachers:

It's been really good because you get to pull students individually or in small groups while they're teaching, and you're able to get more remediation and enrichment activities in, whereas before you couldn't do that.

Group work was the number one thing that I noticed because we could do stations and each of us could have a different station . . . and that made group work move smoother ... [students] didn't have to come up and ask questions.

Co-teachers agreed that the most important effect of 2:1 co-teaching was the positive impact on student achievement growth. Cooperating teachers expressed their satisfaction by reporting: "I could see the growth in the children because of co-teaching teacher candidates, and Co-teaching just works and the students are benefiting and showing so much growth because of it." Cooperating teachers commented on the positive effects of co-teaching in content areas: reading, science, social studies, writing, and math.

One cooperating teacher shared her excitement over students' growth in the area of math, "I've noticed a big improvement in my math scores. We're able to pull students and re-teach, re-teach, re-teach and they get that individualized help." In addition, a cooperating teacher validated the benefit of not having to leave the classroom when teacher candidates were teaching: "The biggest for me was for the kids . . . I am not having to re-do and go back after the all days [to re-teach something]."

As evidenced in comments of cooperating teachers and interns, co-teaching immensely affects students in powerful ways. By improving classroom management and encouraging more differentiation, co-teaching positively affects student growth in tangible ways.

\section{"I Worry About Them in the Real World": Preparation for Teaching}

Nearly all of the cooperating teachers worried about their intern(s) being prepared to enter what they called the "real world". These concerns appeared to stem from the fact that teacher candidates and cooperating teachers in the co-teaching model shared responsibility for planning and instruction, even during the interns' full days when they were accountable for all instruction and classroom responsibilities. Therefore, cooperating teachers did not leave or sit in the back of the room during full days of student teaching as they had in the traditional model. The 2:1 co-teaching model kept all teachers in the classroom actively involved with instruction throughout the semester. Because of this increased teaching time through co-teaching strategies being implemented from the beginning of the semester, the number of full days each teacher candidate was required to complete was reduced. One cooperating teacher saw this as a drawback, comparing it to her own student teaching experience:

I think about everything I had to do and plan for, and you're responsible for everything from start to finish . . with [the co-teaching interns] only having five days, it's just very different compared to what they're going to get [next year]. 
The new requirements for the co-teaching model had many of the cooperating teachers wondering whether their interns would be successful when they got their own classroom. As one cooperating teacher voiced, 'I' $m$ worried that they'll be alone; they won't be fully prepared for that because they haven't been truly alone. There's either another teacher or another intern or a teacher assistant in the room with them most of the time." Working together so closely, some of the teacher candidates began using each other's strengths to improve their own instruction. A cooperating teacher explained that her interns had become very dependent on one another.

They work together, they trade off jobs. So, I'm afraid when they go out on their own, they're not going to know how to do some of the things because the other one has helped them. Another noted, The transition [to their own classroom] might be huge for them . . . when they're in a classroom by [themselves] and probably not going to have a full-time, even a part-time assistant. It's just going to be a huge, huge shock.

Interestingly, despite their concerns about interns entering the "real world" of teaching, cooperating teachers repeatedly conveyed they felt their interns developed teaching skills that would help them in the future. Several cooperating teachers even voiced concerns and benefits of the 2:1 co-teaching model in the same comment. For instance, co-teaching

builds their confidence, and it gives them a stepping stone and maybe to develop some quality lesson plans together and learn classroom management techniques and things like that, but when they get into their own classroom, it's not going to be like this at all.

So, while co-teaching provided interns opportunities to develop and gain confidence in their planning skills and classroom management strategies, the model was still questioned as an effective way to prepare teacher candidates for having their own classroom. Even the teacher candidates had mixed feelings, as one explained, "I feel like this entire internship experience has been a lot less experience than my peers [not in co-teaching] . . . Although I taught a lot more, the experience required more lesson plans, overall the experience has been a lot better." One explanation for the contradictory statements from both cooperating teachers and teacher candidates may be that the co-teaching model is new and quite different than the traditional model of student teaching that most cooperating teachers experienced.

While skepticism of the new co-teaching model was apparent in the majority of the cooperating teachers, all of them voiced benefits to using coteaching and saw evidence of their interns being well-prepared, and in many cases even advantaged, by their experiences with co-teaching. For instance, one cooperating teacher explained that by reducing the student-to-teacher ratio, the co-teachers were able to incorporate more small group work, which allowed "the teachers [interns] to do some things that were maybe more complex and that they would not have been able to do if they'd been the only person there." Another shared that her interns had "more opportunities to teach various types of lesson[s], where with the traditional model of the internship, it would have [been] mostly whole group."

Interns talked about their ability to reflect more deeply on their teaching experiences because they had a co-teaching partner in the room with them. "Having someone there working with you side by side ... having her to reflect [with] on the day really helped. I feel I learned something new every day.”

One teacher candidate talked about her growth and preparation saying, “Looking back, I don't know how I would have gotten through without my coteaching intern. There were some lessons that I had planned that would not have worked without three adults in the room." She went on to explain that she understood in her own classroom next year she might not be able to do the same things but it was a valuable "part of the learning experience" for her.

Cooperating teachers recognized the co-teaching model actually had teacher candidates actively involved in teaching much earlier than the traditional model, as one explained:

I felt free to put them in any situation that I wanted to put them in, right from the day they walked in the door. And I did. Where in traditional [student teaching], you had kids that sat for a week and observed...and then picked up spelling, so it was very orderly in that way, but it was not very productive for them. 
Not being able to sit back and observe, coteaching interns actually had more teaching time than in the traditional model, as one cooperating teacher explained, "They started teaching earlier and getting their hands and feet wet because they sat down immediately [to plan] and said you do this, I'll do that ... the interns got more teaching experience with the co-teaching model." After talking to her peers, one intern shared, "We are teaching so much more." This extra planning and teaching experience was an important component in their preparation and noted by university supervisors as well, "They came along faster, as far as being prepared, than the regular model of the internship." Thus, in spite of legitimate concerns about how "realistic" the co-teaching experience was for the teacher candidates, participants noted growth in classroom management strategies, more opportunities to teach and work with students in various settings, and development of stronger collaborative planning skills.

\section{“They're Master Collaborators by the Time They Finish": Collaboration in the Classroom}

As teacher candidates began their co-teaching experience, it became apparent that they would be collaborating closely with their cooperating teacher and co-intern. They quickly joined co-planning conversations, added to instruction through the use of co-teaching strategies, and claimed ownership of their place in the classroom. A common point made by cooperating teachers was exemplified by the following comment:

They stay until we leave and sometimes we have to push them out the door! They are really positive and collaborated from the start. They talked on the phone, emailed back and forth, and were meeting and planning all the time.

As a result of this commitment to teamwork, several cooperating teachers thought the development of strong collaboration skills was a significant benefit of the co-teaching model. For instance, one commented, "I think collaboration is going to be one of their strong points because that's something they've been doing and have learned to do and another, They're master collaborators by the time they finish."
Co-teaching interns actively participated in the planning for instruction in the classroom, as well as at grade-level planning meetings. For some, it was difficult to find enough time in a day to plan together (teacher candidates and cooperating teachers) for the level of co-teaching they found themselves doing and wanting to do. Other teacher candidates found or created opportunities to plan daily with their cointern and found it very helpful, as one intern noted:

\begin{abstract}
You can bounce ideas off each other. I might have an idea that I think is fantastic and maybe one of my peers has tried it before . . . and it was a nightmare or I did that and it worked fabulously, so I think it is very helpful to plan together.
\end{abstract}

Another intern commented, "One of the most positive things that I found was with planning." She felt that because she and her co-intern were at the same place in their schooling and teacher preparation, they could help each other more effectively. "I feel like that was one of the most powerful things because I wasn't by myself in planning. I had another student teacher, before I had to turn my plans in, so that was really, really helpful."

In addition to co-planning, teacher candidates had more teaching opportunities than non co-teaching interns. These opportunities allowed them to see multiple teaching styles, classroom management strategies, and ways of working with students. Some were surprised by the level of comfort they had in coteaching, which was evident in this intern's experience:

\footnotetext{
We did a lot of team teaching ... towards the end of internship [we were using] not even planned team teaching - just if I was saying something, he would come in and give another example; if he was teaching, I would relate it back to something that he did in the other [lesson] ... it was very natural, which I did not anticipate.
}

Cooperating teachers also saw the value of two teacher candidates working together to plan and teach lessons. One shared that her interns collaborated well and early: "[They] found out the strengths of each other and were able to [use them] ... One was 
stronger with technology, one stronger with finding books . . . they helped each other, trading off duties and tasks. That's been pretty cool to watch." Their teaching was stronger and more effective when they prepared materials and taught together. One intern noted, "I just feel like the collaboration and support that you get from having another intern in the room did wonders for me and my teaching."

One last skill that co-teaching teacher candidates developed, through collaboration with co-teaching peers, was the ability to reflect on their teaching. One cooperating teacher noted that her teacher candidates did "a lot of reflecting with each other . . . which is something that I've not ever heard before because a traditional intern didn't have anybody to say it to, except me, and I think they're trying to please us." A second veteran cooperating teacher recognized this same phenomenon and felt that because of their position of authority "they think we're grading them" and interns were not as open with them in their reflection on student learning or their teaching. She explained, "I'm right here in the room and I can hear them, and they do a lot of [reflecting], that I haven't seen before. And I think that's important. I mean, I reflect every day still."

Traditional student teaching experiences tend to position cooperating teachers as master teacher and mentor while teacher candidates are receivers of their knowledge and experience in teaching. An interesting find in the data suggests that co-teaching provided opportunities for cooperating teachers to also gain knowledge from their co-teaching interns. Because teacher candidates regularly participated in coplanning with the cooperating teacher and grade-level teams, they quickly gained confidence in their professional knowledge and were seen as more active than their non co-teaching counterparts in collaborative discussions with other teachers. Bringing current best practices in instruction and a strong understanding of Common Core Standards from their course work at the university, teacher candidates influenced instruction as much as the inservice teachers, as evident in this observation by a cooperating teacher, "We had a PLC [professional learning community] meeting and were talking about our next science topic, and [the intern] was naming off what we're supposed to do, and I'm like 'how come you know this better than I do?" Cooperating teachers valued the knowledge base of teacher candidates, recognizing how it added to their own information and experience to enhance planning. "They can look at the big picture when we're drowning in the details. We're so busy with the details that any details we leave out, they'll remember." Cooperating teachers and grade level teachers viewed the interns as colleagues rather than simply students learning to teach. Such collaborative opportunities appear to be a win-win for both interns and cooperating teachers.

Learning to teach is more than just planning strong and effective lesson plans and managing a classroom. There are professional dispositions that are important to acquire to become an effective teacher. One cooperating teacher explained this idea by saying:

As far as professionalism and what's expected to run a classroom, it's not just the mechanics of teaching. It is the internal part. What you have within and how you use that and how you work with your colleagues down the hall. If they watch a clinical teacher that does not interact with colleagues, they're not going to know that's what they're supposed to do ... if that clinical teacher doesn't model that, they won't ever get it.

Modeled professionalism and opportunities to collaborate fully with peers and cooperating teachers developed not only confidence in their efficacy to teach but collaborative skills needed in schools.

\section{Discussion}

In our work with co-teaching, we found that selection of quality cooperating teachers willing to share their classroom through co-teaching was a vital component of our teacher candidates' success. This finding is key as research shows cooperating teachers have the most significant impact on teacher candidates (Anderson, 2009; Killian \& Wilkins, 2009; Whitney, Golez, Nagel, \& Nieto, 2002). However, selection of cooperating teachers is difficult given current educational reforms calling for teacher evaluation to be tied directly to student achievement and a greater hesitancy among veteran teachers to take interns (Sinclair et al., 2006; Zeichner, 2002). Co-teaching in teacher preparation allows cooperating teachers to mentor teacher 
candidates, yet maintain an instructional presence in their classroom, which was a draw for administrators and cooperating teachers in the study.

While the impact of cooperating teachers is significant, the relationship that forms between them and teacher candidates is also important in developing efficacy in the responsibilities of teaching. This study found the structure of the coteaching internship moved teacher candidates to take on collaborative responsibilities for planning, teaching, and student assessment sooner than the traditional model of student teaching. Involving teacher candidates through co-planning removed some of the sharp distinctions between novice and experienced classroom teachers found in traditional placements (Carambo \& Stickney, 2009). Strong collaborative opportunities also provided veteran teachers current understandings of curriculum and teaching strategies as our interns shared their learning in concrete ways during co-planning and co-teaching. Interns felt part of the teaching team and were able to contribute in meaningful ways, which ultimately led to increased confidence in their efficacy to teach and collaborate in their future work.

\section{Implications for Teacher Education}

The past decade has seen an increase in teacher education reform; however, the last century has seen little change to the student teaching experience (Guyton \& McIntyre, 1990). Given the responsibility on teacher education programs to provide teacher candidates with relevant, well-planned, and effectual teaching experiences (Council of Chief State School Officers, 2012), it is time to consider revitalizing, or perhaps reviving, the clinical experiences for our students. Co-teaching offers opportunities for teacher education programs to (a) be more selective in choosing cooperating teachers; (b) engage teacher candidates in meaningful collaboration on planning, teaching, and assessing student learning, and (c) give back to our public school partners and impact student achievement.

Teacher education programs must choose veteran teachers who best model effective teaching and classroom management strategies, involve teacher candidates in co-planning and assessment of student learning, and engage them in meaningful reflection.
The use of the 2:1 model of co-teaching lowers the number of cooperating teachers creating the ability for teacher education programs to be more selective in finding clinical placements for teacher candidates.

A growing number of administrators are seeking candidates with collaborative experience. Coteaching allows teacher candidates to develop not only collaborative skills needed but increased efficacy in co-planning, teaching, and assessment.

With mounting pressures on schools to increase student achievement, teacher education programs have a responsibility to assist in this endeavor rather than add to the burden through traditional student teaching placements. Co-teaching, especially the 2:1 model, offers schools support by having more teachers within the classrooms, minimalizing behavioral issues, and providing more individualized and differentiated instruction.

\section{Limitations of the Study}

A challenge we faced in conducting this study was the number of participants randomly selected to co-teach from the pool of 210 teacher candidates in 2011-2012. The number of co-teaching participants selected was much smaller than the number of non co-teaching participants. Co-teaching teacher candidates that participated in the study totaled 25 in comparison to the 185 non co-teaching teacher candidates. Therefore, data collected on participants was limited regarding their experience with coteaching, not allowing for generalization.

The 2:1 co-teaching model, while a promising innovation, lacks a research base since it is a new model of Co-Teaching. No literature exists at this point to support or discount the innovation. The present study is the first attempt to study the $2: 1$ model in comparison to the established 1:1 coteaching model researched and published by St. Cloud University.

\section{Future Research}

We have extended our study to include more participants with an evenly matched number of coteaching vs. non co-teaching teacher candidates. As well, the new study includes equal numbers of $1: 1$ 
and 2:1 co-teaching classrooms. Current data collection involves four times as many participants, which will allow us to generalize findings. These changes will give us the ability to look at differences between and examine the effects of different placements in rural settings.

In addition, the co-teaching innovation at our university plans to investigate the feasibility of a year-long co-teaching internship where Senior 1 and Senior 2 teacher candidates co-teach together in the same classroom. The Senior 1 teacher candidate gains experience co-teaching not only with the clinical teacher but also co-teaching with a Senior 2 teacher candidate that is completing his/her teacher education program. What are the benefits to this type of co-teaching pairing? How does this model impact student achievement in rural K-12 classrooms?

One final area of future research involves following our graduates into the field during the first few years of teaching. Are there differences in ratings by administrators in graduates who co-taught and those who did not? How are graduates who co-taught perceived by their peers in terms of collaboration and teaching? How does co-teaching during internship impact those first years of teaching particularly in rural school districts?

\section{Conclusion}

The co-teaching model for student teaching explored in this article supports engaging, collaborative teaching opportunities for teacher candidates and cooperating teachers that suggest not only quicker growth in teaching effectiveness of interns, but also potential student improvement in cotaught classrooms.

Additionally, the 2:1 co-teaching model provides possible solutions to the problems of finding adequate, quality teaching placements in predominantly rural public school settings. Reducing the number of placements promises more selectivity in the already limited number of placements available in rural areas and thus enhances the quality of those placements.

Collaborative skills are greatly enhanced in the 2:1 co-teaching model with emphasis on lending support and trust building with co-teaching colleagues, co-planning for optimal student learning, and an ability to reflect on instructional practice with colleagues. Co-teaching allows teacher candidates to develop stronger relationships with cooperating teachers and peers while also gaining efficacy in their readiness to teach. Ultimately, co-teaching holds tremendous potential for raising student achievement, especially for diverse learners. Opportunities for differentiation abound in co-teaching placements, resulting in greater impacts on positive student growth outcomes and valuable teaching experiences for interns.

The 2:1 co-teaching model of student teaching offers teacher education programs the need for fewer placements, which ultimately allows the selection of quality cooperating teachers who can mentor interns in powerful ways. This means that regardless of rural or urban contexts, teacher preparation programs can improve clinical opportunities for their teacher candidates.

\section{References}

Academy for Co-Teaching and Collaboration. (2012). Mentoring teacher candidates through coteaching [Train-the-Trainer Workshop]. St. Cloud State University, St. Cloud, MN.

Adams, L., \& Cessna, K. (1991). Designing systems to facilitate collaboration: Collective wisdom from Colorado. Preventing School Failure, 35(4), 37-42.

Adams, L., Cessna, K., \& Friend, M. (1993). Effectiveness indicators of collaboration in special education/general education coteaching: Final report. Denver, CO: Colorado Department of Education. 
Anderson, D. (2009). The impact of cooperating teachers on the teaching perspectives of student teachers. The International Journal of Learning, 16(1), 119-133.

Austin, V. L. (2001). Teachers' beliefs about coteaching. Remedial and Special Education, 22(4), 245-255. doi: $10.1177 / 074193250102200408$

Barley, Z. A. (2009). Preparing teachers for rural appointments: Lessons from the mid-continent. The Rural Educator, 30(3), 10-15.

Bauwens, J., \& Hourcade, J. J. (1991). Making coteaching a mainstreaming strategy. Preventing School Failure, 35(4), 19-24.

Bauwens, J., \& Hourcade, J. J. (1997). Cooperative teaching: Pictures of possibilities. Intervention in School and Clinic, 33(2), 81-85. doi: $10.1177 / 105345129703300202$

Beninghof, A. M. (2011). Co-teaching that works: Effective strategies for working together in today's inclusive classrooms. Hoboken, NJ: John Wiley \& Sons, Inc..

Boucka, E. C. (2007). Co-teaching...not just a textbook term: Implications for practice.

Preventing School Failure: Alternative Education for Children and Youth, 51(2), 46-51.

Carambo, C., \& Stickney, C. T. (2009). Coteaching praxis and professional service: Facilitating the transition of beliefs and practices. Cultural Studies of Science Education, 4(2), 433-441.

Cochran-Smith, M., \& Fries, M. K. (2001). Sticks, stones, and ideology: The discourse of reform in teacher education. Educational Researcher, 30(8), 3-15.

Cook, L., \& Friend, M. (1995). Co-teaching: Guidelines for creating effective practices. Focus on Exceptional Children, 28(3), 1-16.

Council of Chief State School Officers (CCSSO). (2012). Our responsibility, our promise: Transforming educator preparation and entry into the profession. Retrieved from:
http://www.ccsso.org/Documents/2012/Our Responsibility Our Promise_2012.pdf

Creswell, J. W. (2005). Educational research: Planning, conducting, and evaluating quantitative and qualitative research (2nd ed.). Upper Saddle River, NJ: Pearson Education, Inc.

Delandshere, G., \& Petrosky, A. (2004). Political rationales and ideological stances of the standards-based reform of teacher education in the US. Teaching and Teacher Education, 20(1), 1-15.

Friend, M. (2001, February). Co-teaching for general and special educators. Paper presented at Clark County School District, Las Vegas, NV.

Gay, G. (2000). Culturally responsive teaching: Theory, research, and practice. New York: Teachers College Press.

Gollnick, D. M., \& Chinn, P. C. (2009). Multicultural education in a pluralistic society (8th ed.). Upper Saddle River, NJ: Pearson Education, Inc.

Goodlad, J. (1994). The national network for educational renewal. Phi Delta Kappan, 75(8), 632-639.

Guyton, E., \& McIntyre, D. (1990). Student teaching and school experiences. In W. Houston (Ed.), Handbook of research on teacher education (pp. 514-534). New York: Macmillan.

Hang, Q., \& Rabren, K. (2009). An examination of co-teaching perspectives and efficacy indicators. Remedial and Special Education, 30(5), 259268.

Harmon, H. L., \& Smith, K. C. (2012). Legacy of the rural systemic initiatives: Innovation, leadership, teacher development, and lessons learned. Charleston: WV: Edvantia, Inc. Retrieved from http://files.eric.ed.gov/fulltext/ED531890.pdf

Hudson, P. B., \& Hudson, S. M. (2008). Changing preservice teachers' attitudes for teaching in rural schools. Australian Journal of Teacher Education, 33(4), 67-77. 
Irvine, J. J. (2003). Educating teachers for diversity: Seeing with a cultural eye. New York: Teachers College Press.

Jones, A. (2011). Rethinking the rural practicum. Paper presented at the Annual Meeting of the American Educational Research Association. ERIC. Online Submission.

Killian, J. E., \& Wilkins, E. A. (2009) Characteristics of highly effective cooperating teachers: A study of their backgrounds and preparation. Action in Teacher Education, 30(4), 67-83. doi: 10.1080/01626620.2009.10734453

Ladson-Billings, G. (2001). No teacher left behind: Issues of equity and teacher quality. In C.A. Dwyer (Ed.), Measurement and Research in the Accountability Era. (pp. 141-162). Erlbaum Mahwah, NJ: Routledge.

Ladson-Billings, G. (2004). New directions in multicultural education: Complexities, boundaries, and critical race theory. In J. Banks \& C. A. McGee Banks (Eds.), Handbook of research on multicultural education. (pp. 50-65). San Francisco, CA: John Wiley \& Sons, Inc.

Lock, G., Reid, J. A., Green, B., Hastings, W., Cooper, M., \& White, S. (2009). Researching rural-regional (teacher) education in Australia. Education in Rural Australia, 19(2), 31-44.

MetLife, Inc. (2013, April). The MetLife Survey of the American Teacher: Listening to Teachers in Rural Schools. Paper presented at the National Conference on Rural Education Research, Omaha, NE.

Murphy, P., \& Cross, W. (1990). Preparing teachers for rural schools: A Canadian approach. The Rural Educator, 11(3), 10-11.

The National Center for Education Statistics. (2012). Rural education in America. Retrieved June 26, 2014, from http://nces.ed.gov/surveys/ruraled/

National Council on Teacher Quality. (2011). State of the states: Trends and early lessons on teacher evaluation and effectiveness policies. Washington, D.C.: National Council on Teacher
Quality. Retrieved from

http://www.nctq.org/p/publications/docs/nctq_sta teOfTheStates.pdf

Nganga, L., \& Laughlin, P. (2011). Preparing culturally responsive rural early childhood educators: Infusing diversity into multiple course work. In D.T. Williams \& T.L. Mann (Eds.) Early childhood education in rural communities: Access and quality issues (pp.119-145). Fairfax, VA: UNCF/Frederick D. Patterson Research Institute.

Ralph, E. G. (2002). Teaching in rural schools: A synthesis of interns and cooperating teachers' views. The Rural Educator, 24(2), 13-22.

Reeve, P. T., \& Hallahan, D. P. (1994). Practical questions about collaboration between general and special educators. Focus on Exceptional Children, 26(7), 1-10.

Ruys, I., Van Keer, H., \& Aelterman, A. (2010). Collaborative learning in pre-service teacher education: An exploratory study on related conceptions, self-efficacy and implementation. Educational Studies, 36(5), 537-553.

Sharplin, E. (2002). Rural retreat or outback hell: Expectations of rural and remote teaching. Issues in Educational Research, 12(1), 49-63.

Sileo, J. M. (2005, August). Co-teaching: Best practices for education. In Inclusive and Supportive Education Congress International Special Education Conference Inclusion: Celebrating Diversity? Retrieved from http://www.isec2005.org.uk/isec/abstracts/papers _s/sileo_j.shtml

Sinclair, C., Dawson, M., \& Thistleton-Martin, J. (2006). Motivations and profiles of cooperating teachers: Who volunteers and why? Teaching and Teacher Education, 22, 263-279.

Stake, R. (2000). Qualitative case studies. In N. K. Denzin \& Y. S. Lincoln (Eds.), Handbook of qualitative research ( 2 nd ed., pp. 443-466). Thousand Oaks, CA: Sage. 
Vaughn, S., Schumm, J. S., \& Arguelle, M. (1997).

The ABCDEs of co-teaching. Teaching

Exceptional Children, 30, 4-10.

Wang, J., Odell, S. J., Klecka, C. L., Spalding, E., \& Lin, E. (2010). Understanding teacher education reform. Journal of Teacher Education, 61(5), 395-402.

White, S., \& Kline, J. (2012). Developing a rural teacher education curriculum package.

The Rural Educator, 33(2), 36-43.
Whitney, L., Golez, F., Nagel, G., \& Nieto, C. (2002). Listening to voices of practicing teachers to examine the effectiveness of a teacher education program. Action in Teacher Education, 23(4), 69-76.

Yarrow, A., Ballantyne, R., Hansford, B., Herschell, P., \& Millwater, J. (1999). Teaching in rural and remote schools: A literature review. Teaching and Teacher Education, 15(1), 1-13.

Zeichner, K. (2002). Beyond traditional structures of student teaching. Teacher Education Quarterly, 29(2), 59-64.

About the authors:

Christina M. Tschida is an Assistant Professor of elementary education and social studies education. Her primary research areas are teacher education, online teaching and learning, culturally responsive teaching, and social studies instruction. She has presented nationally at AACTE, AERA, NCSS, CUFA, SITE, and NAME. tschidac@ecu.edu

Judith J. Smith is an Associate Professor of elementary education. Her primary research areas are teacher education, language/literacy, and educational technology $/ 21^{\text {st }}$ century literacies. She has presented nationally at AACTE, ELEARN, SITE, AERA, LRA, and AACE.

Elizabeth Fogarty is an Associate Professor of elementary education. Her research focuses on teacher effectiveness, including teachers' ability to differentiate and meet the needs of gifted learners. Dr. Fogarty advocates for gifted children and their teachers through several professional organizations. 